\title{
Biodegradable Quaternary Ammonium Salts for Processing Iron Ores
}

\author{
Xiaoqing Weng1,2*, Anh V. Nguyen², Guangjun Mei1", Yongfu Yu1 \\ ${ }^{1}$ School of Resources and Environmental Engineering, Wuhan University of Technology, Wuhan, China \\ ${ }^{2}$ School of Chemical Engineering, The University of Queensland, Brisbane, Australia \\ Email: xaoqingw@163.com, ${ }^{*}$ meiguangjun@yahoo.com.cn
}

Received 6 May 2014; revised 19 June 2014; accepted 30 June 2014

Copyright (C) 2014 by authors and Scientific Research Publishing Inc.

This work is licensed under the Creative Commons Attribution International License (CC BY).

http://creativecommons.org/licenses/by/4.0/

c) (i) Open Access

\begin{abstract}
Two biodegradable quaternary ammonium salts were synthesized and used as cationic collectors in processing iron ores by froth flotation. The flotation behaviors of iron minerals with the new biodegradable quaternary ammonium collectors were investigated by micro-flotation tests of quartz $\left(\mathrm{SiO}_{2}\right)$ and magnetite $\left(\mathrm{Fe}_{3} \mathrm{O}_{4}\right)$. It was observed that the new biodegradable collectors were effective in separating quartz from magnetite by flotation. At the collector concentration of $1 \times$ $1^{-4} \mathrm{~mol} / \mathrm{L}$, the recovery of quartz using the M301 and M302 collectors can reach its maximum of $67.97 \%$ and $91.18 \%$, respectively. For a wide $\mathrm{pH}$ range, they also show good selectivity. By the measuring zeta potentials of the new quaternary ammonium salts, the results show that quaternary ammonium salt is preferred to adsorb on the surface of quartz. The two quaternary ammonium collectors are also determined as readily biodegradable collectors, according to the OECD301B evaluation standard.
\end{abstract}

\section{Keywords}

Quaternary Ammonium Salt, Micro-Flotation, Zeta Potential, Biodegradation

\section{Introduction}

Cationic surfactants are widely used in the industry, from biotechnology, medicine and pharmacology to biocide production. Quaternary ammonium salts (QAS) belong to an important class of cationic surfactants and can be used as fabric softeners, antistatic agents, germicides and additives associated with chemical reactions. They are molecules with at least one long, hydrophobic alkyl chain attached to a positively charged nitrogen atom [1]. Because QAS can render hydrophobicity to the negatively charged mineral particles in an ore pulp and enable

${ }^{*}$ Corresponding authors. 
them to be concentrated into a froth concentrate, QAS find application in froth flotation. Hu et al. studied quantitative structure-activity relationships between QAS collectors and bauxite $\left(\mathrm{Al}_{2} \mathrm{O}_{3}\right)$ reverse flotation, which show good flotation and adsorption behavior [2]-[4].

Regarding the relative floatabilities of iron oxide minerals, quartz and silicate minerals in iron ore processing, reverse flotation of quartz using cationic collectors is the most important technique for concentrating iron ores. In this flotation system, the QAS are adsorbed on the quartz surface, and both are removed from the system by air bubbles as a froth product. In this work, microflotation of the key minerals (quartz and magnetite) was employed to test the flotation behavior of the new QAS collectors.

Importantly, for the behavior of cationic collectors in tailings, in particular, their degradation is not completely understood although some studies into amine biodegradation have been reported [5]-[8]. With the ongoing worldwide demand for iron ores, cationic collector consumption tends to constantly increase. Many tons of flotation reagents are discharged into the aquatic environment with waste water from iron ore processing plant each year. Environmental concerns have become one of the main driving forces for the development of new flotation reagents with higher efficiency and biodegradability. The biodegradation rate has become a major interest. One approach is to introduce an easily cleavable bond into the surfactant structure. Seemingly, for most surfactants containing easily cleavable bonds, the values for ultimate decomposition are higher than those for the corresponding surfactants lacking the weak bond [9] [10]. An important example of such cleavable surfactants is the esterquats, which are surfactants with an ester bond inserted between the polar quaternary ammonium head group and the hydrophobic tail of the surfactant [11].

In this study, we focus on synthesis of QAS with ester bond. Herein, two novel esterquats, namely, N-(2-hydroxyl-3-lauryloyloxypropyl) dimethyl dodecyl ammonium chloride (M301) and 3,3'-adipoyloxy-2,2'-dihydroxy dipropanyl bis (cetyl dimethyl ammonium) dichloride (M302), were prepared, characterized and tested. The difference in flotation behaviors of iron ore with M301 and M302 was identified and discussed. Adsorption mechanisms of quaternary ammonium cationic collectors on magnetite and quartz were investigated by changes in the surface potentials by adsorbed surfactant molecules. The ultimate biodegradability was determined by the $\mathrm{CO}_{2}$ evolution test (OECD301B, ISO9439) classification standards [12] [13].

\section{Materials and Methods}

\subsection{Minerals}

Mineral crystals of magnetite and quartz were obtained from the Julius Kruttschnitt Mineral Research Centre at the Sustainable Minerals Institute, The University of Queensland, Brisbane, Australia. The measured $d_{50}$ for the silica sample was $24.5 \mu \mathrm{m}$, and the $\mathrm{d}_{80}$ was $55.7 \mu \mathrm{m}$, while for the magnetite particles of similar sizes, $\mathrm{d}_{50}$ was $31.3 \mu \mathrm{m}, \mathrm{d}_{80}$ was $57.3 \mu \mathrm{m}$. They were of $90 \%$ purity based on mineralogical analysis and chemical analysis. The results of chemical analysis are given in Table 1.

\subsection{Chemicals}

The novel cationic surfactants were synthesized in the laboratory using the raw materials of dodecyl dimethyl ammonium and epichlorohydrin (both from Tian-jing Chemicals, China), and dodecanoic acid and adipic acid (both from Sigma-Aldrich, Australia). The synthesis route is shown in Figure 1.

Deionized water was obtained from a Milli-Q system (Millipore, USA) and used in all experiments. pH control was achieved using dilute solutions of $\mathrm{HCl}$ and $\mathrm{NaOH}$.

\subsection{Microflotation Tests}

The flotation experiments were performed in a laboratory XFGC II flotation machine (Jilin Resource Explora-

Table 1. Chemical analysis results of magnetite and quartz (mass fraction, \%).

\begin{tabular}{ccccccccc} 
Composition & $\mathrm{SiO}_{2}$ & $\mathrm{Al}_{2} \mathrm{O}_{3}$ & Total Fe & $\mathrm{Fe}_{2} \mathrm{O}_{3}$ & $\mathrm{~S}$ & $\mathrm{P}$ & $\mathrm{Cu}$ & $\mathrm{H}_{2} \mathrm{O}\left(110^{\circ} \mathrm{C}\right)$ \\
\hline Magnetite & 1.4 & 0.8 & 69.5 & 1.0 & 0.4 & 0.02 & 0.005 & 1.0 max \\
Composition & $\mathrm{SiO}_{2}$ & $\mathrm{Al}_{2} \mathrm{O}_{3}$ & $\mathrm{Fe}_{2} \mathrm{O}_{3}$ & Titania & Lime & Loss on ignition $\left(1000^{\circ} \mathrm{C}\right)$ \\
Quartz & 99.6 & 0.1 & 0.02 & 0.02 & $<0.1 \%$ & & 0.2 \\
\hline
\end{tabular}




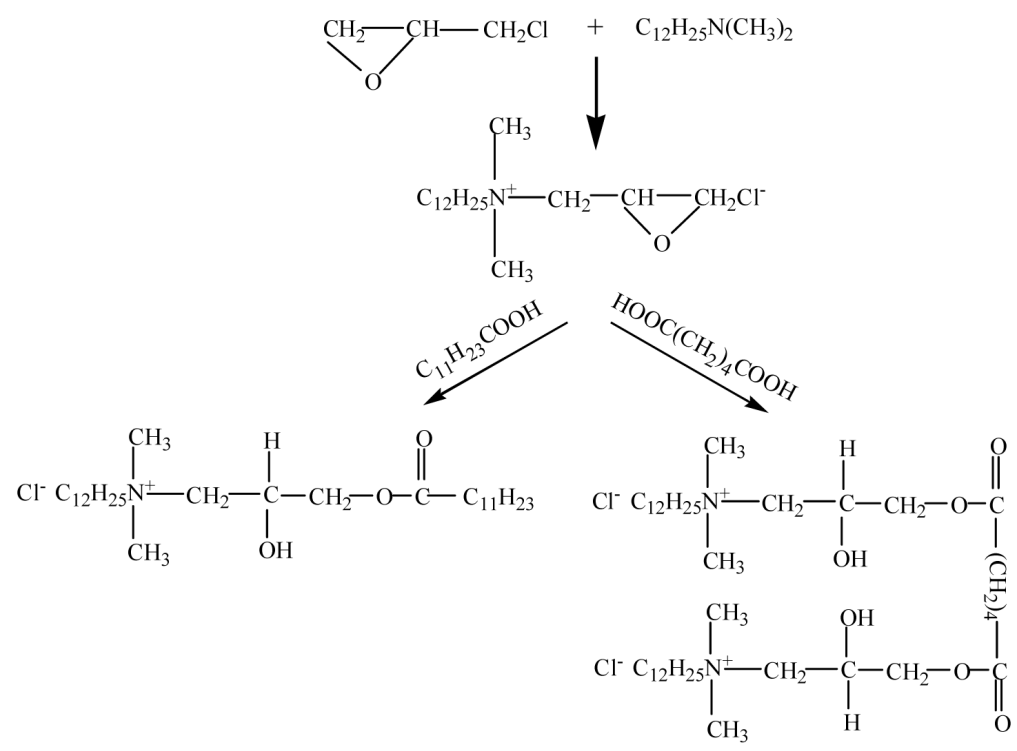

Figure 1. Synthesis route for esterquats.

tion Mechanical Factory, China). Microflotation tests were carried out by using mineral crystals of quartz and magnetite in a $40 \mathrm{~mL}$ flotation cell. Each flotation test used $3 \mathrm{~g}$ of mineral sample and was performed at 1600 rpm. After adding the desired amount of collectors, the suspension was agitated for 3 min and the pH was measured and adjusted before introducing air into the flotation cell. Collectors were conditioned for 2 min. The flotation was conducted for $6 \mathrm{~min}$. The products were dried and weighed. The recovery was calculated based on the dry weights of the products obtained.

\subsection{FTIR Spectroscopy}

Infrared spectra were collected using KBr discs on a Perkin-Elmer 2000 FTIR after 40 scans within 4000 - 400 $\mathrm{cm}^{-1}$ at a resolution of $2 \mathrm{~cm}^{-1}$.

\subsection{Surface Potential Measurements}

The surface (zeta) potential of particles was measured using ZetaPlus (Brookhaven Instrument Cor., USA). The mineral samples were ground to $<38 \mu \mathrm{m}$ using a mortar and pestle. Then, the ground sample was added into 50 $\mathrm{mL}$ solutions of $1 \mathrm{mM} \mathrm{KCl}$ solution (0.01 wt\%) with different pHs. Solutions were adjusted using $0.1 \mathrm{M} \mathrm{HCl}$ and $\mathrm{NaOH}$, and the suspension was shaken for $5 \mathrm{~min}$. Finally, $5 \mathrm{~mL}$ of the suspension was transferred to the measuring cell. The zeta potential distributions for magnetite and quartz were obtained in the absence and presence of cationic collectors. Each experiment series was repeated 3 times. The zeta potential values were averaged and reported.

\subsection{Biodegradation Measurements}

The Closed Bottle test, a standardized method (OECD301B), was used for evaluating the ultimate biodegradability of novel cationic collectors. This method has previously been described in details [13] and will be discussed briefly here. The source of inoculums is activated sludge from wastewater treatment plant of Wuhan University of Science and Technology Zhongnan branch, the activated sludge concentration was $15 \mathrm{mg} \cdot \mathrm{L}^{-1}$. The concentration of the test compound was $20 \mathrm{mg} \cdot \mathrm{L}^{-1}$. The basal medium in the aerobic biodegradation tests contained: $36.40 \mathrm{~g} \cdot \mathrm{L}^{-1} \mathrm{CaCl}_{2} \cdot 2 \mathrm{H}_{2} \mathrm{O}, 22.5 \mathrm{~g} \cdot \mathrm{L}^{-1} \mathrm{MgSO}_{4} \cdot 7 \mathrm{H}_{2} \mathrm{O}, 0.25 \mathrm{~g} \cdot \mathrm{L}^{-1} \mathrm{FeC1}_{3} \cdot 6 \mathrm{H}_{2} \mathrm{O}, 8.5 \mathrm{~g} \mathrm{KH}_{2} \mathrm{PO}_{4}, 21.75 \mathrm{~g}$ $\mathrm{K}_{2} \mathrm{HPO}_{4}, 36.40 \mathrm{~g} \mathrm{Na}_{2} \mathrm{HPO}_{4} \cdot 2 \mathrm{H}_{2} \mathrm{O}, 0.50 \mathrm{~g} \mathrm{NH} \mathrm{Cl} \mathrm{Cl}$ dissolved in $1000 \mathrm{~mL}$ distilled water, $\mathrm{pH}=7.4$. Test period is 28 days [13].

$$
\% \mathrm{D}=[(\mathrm{CO})-(\mathrm{CO}) / \mathrm{ThCO}] \times 100
$$


In Equation (1), \%D is the percentage biodegradation, $\left(\mathrm{CO}_{2}\right)_{\mathrm{T}}$ is the amount of $\mathrm{CO}_{2}$ evolved in each bioreactor containing tested material $(\mathrm{mg}),\left(\mathrm{CO}_{2}\right)_{\mathrm{B}}$ is the amount of $\mathrm{CO}_{2}$ evolved in the blank bioreactor $(\mathrm{mg})$. According to OECD301B evaluation standard, organic matter can be divided into three categories as shown in Table 2.

\section{Results and Discussion}

\subsection{Characterization}

The Fourier transform infrared spectra of M301 and M302 are shown in Figure 2. Three kinds of bands are observed at around $3410 \mathrm{~cm}^{-1}$ (the stretch vibration absorption of $\mathrm{OH}$ ), $3000 \mathrm{~cm}^{-1}$ and $2850 \mathrm{~cm}^{-1}$ (the antisymmetric and symmetric stretch vibration absorption of $\mathrm{CH}_{3}, \mathrm{CH}_{2}$ and $\mathrm{CH}$ ). From Figure 2, the prominent peak of M301 and M302 at around $1720-1740 \mathrm{~cm}^{-1}$ are due to carbonyl stretching vibration. The weak IR band near $1169 \mathrm{~cm}^{-1}$ and $1110 \mathrm{~cm}^{-1}$ comes from the stretch vibration absorption of C-O in ester bond, which confirmed the formation of the ester. The weakening of a peak at $3000-3500 \mathrm{~cm}^{-1}$ shows the obvious decrease of hydroxyl groups. In addition, the band observed at $988 \mathrm{~cm}^{-1}$ and $720 \mathrm{~cm}^{-1}$ from both Figure 2(A) and Figure 2(B) come from the special absorption of quaternary ammonium salt and the special vibration absorption respectively.

\subsection{Microflotation of Mineral Crystals}

The flotation results for M301 and M302 collectors are shown in Figures 3-5. Figure 3 shows that both M301 and M302 have a better collection performance to quartz than magnetite. It is evident that M302 has a stronger collect ability than M302 in a wide range of operating conditions. The flotation recovery of quartz increases sharply with increasing concentration of collector. When the concentration of collectors reaches $1 \times 10^{-4} \mathrm{~mol} / \mathrm{L}$, the flotation recovery of quartz reaches its maximum for $67.97 \%$ with M301 and $91.18 \%$ with M302. The collection ability of M301 and M302 for magnetite is low and the flotation recovery is below 50\% under the experimental condition. When the concentration reaches $5 \times 10^{-4} \mathrm{~mol} / \mathrm{L}$, the magnetite recovery has a maximum of $21.69 \%$ with M301 and $42.01 \%$ with M302. In order to remove quartz from magnetite, $1 \times 10^{-4} \mathrm{~mol} / \mathrm{L}$ is a suitable collector concentration for removing quartz from magnetite to meet the requirement of reverse flotation of iron ore.

The flotation behaviors of quartz and magnetite as a function of pH using M301 and M302 as collectors with concentration $1 \times 10^{-4} \mathrm{~mol} / \mathrm{L}$ are shown in Figure 4 and Figure 5. Figure 4 indicates M301 has a good selectivity in the $\mathrm{pH}$ range of $5-11$, and when $\mathrm{pH}$ reaches to 9 , the recovery of quartz is at its maximum of $83.4 \%$. In Figure 5, M302 shows a high selectivity for the flotation separation of quartz from magnetite as pH increases.

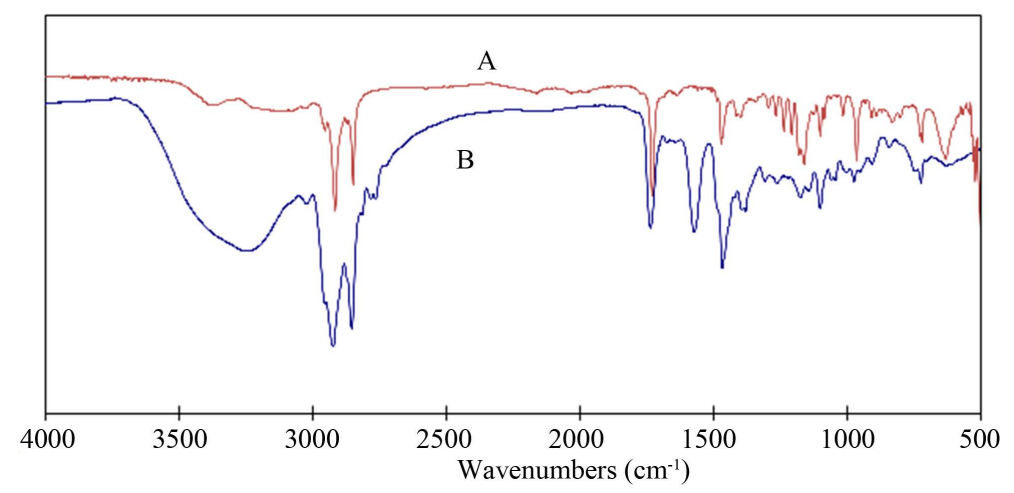

Figure 2. IR transmission spectra of M301 and M302.

Table 2. Evaluation standard of biodegradation.

\begin{tabular}{cc} 
Degeneration situation & Biodegradability \\
$\eta 10<10 \%$ & Poorly biodegradable \\
$\eta 10>10 \% \eta 10<60 \%$ & Partially biodegradable \\
$\eta 10>10 \% \eta 10>60 \%$ & Readily biodegradable \\
\hline
\end{tabular}




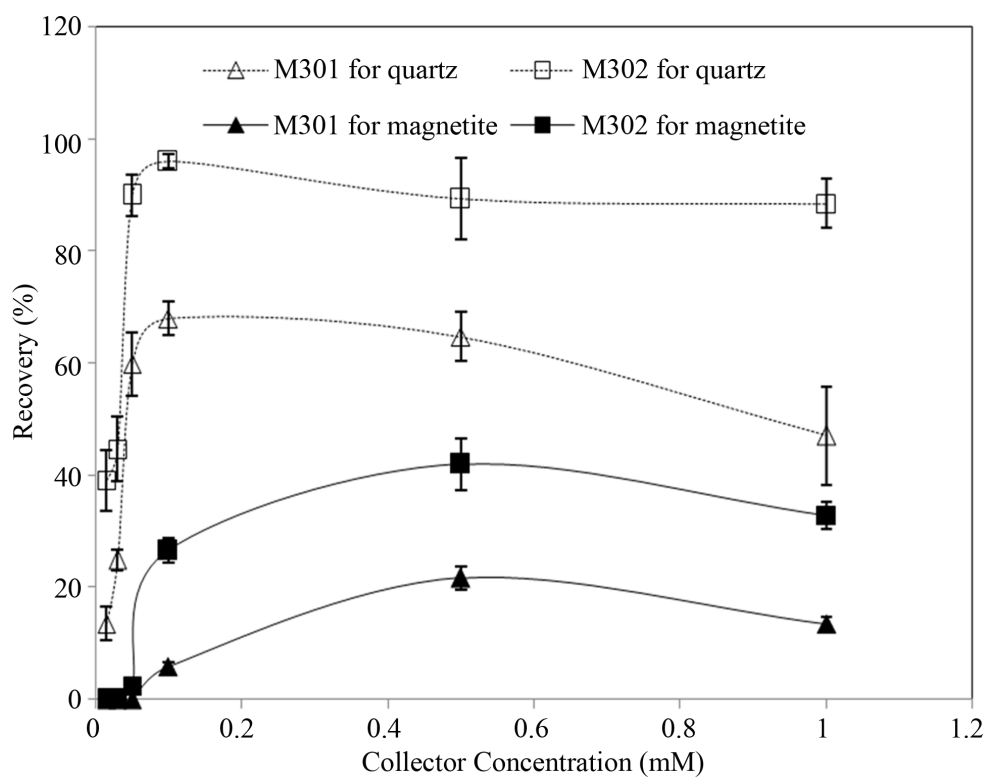

Figure 3. Effects of M301 and M302 concentration on minerals recoveries.

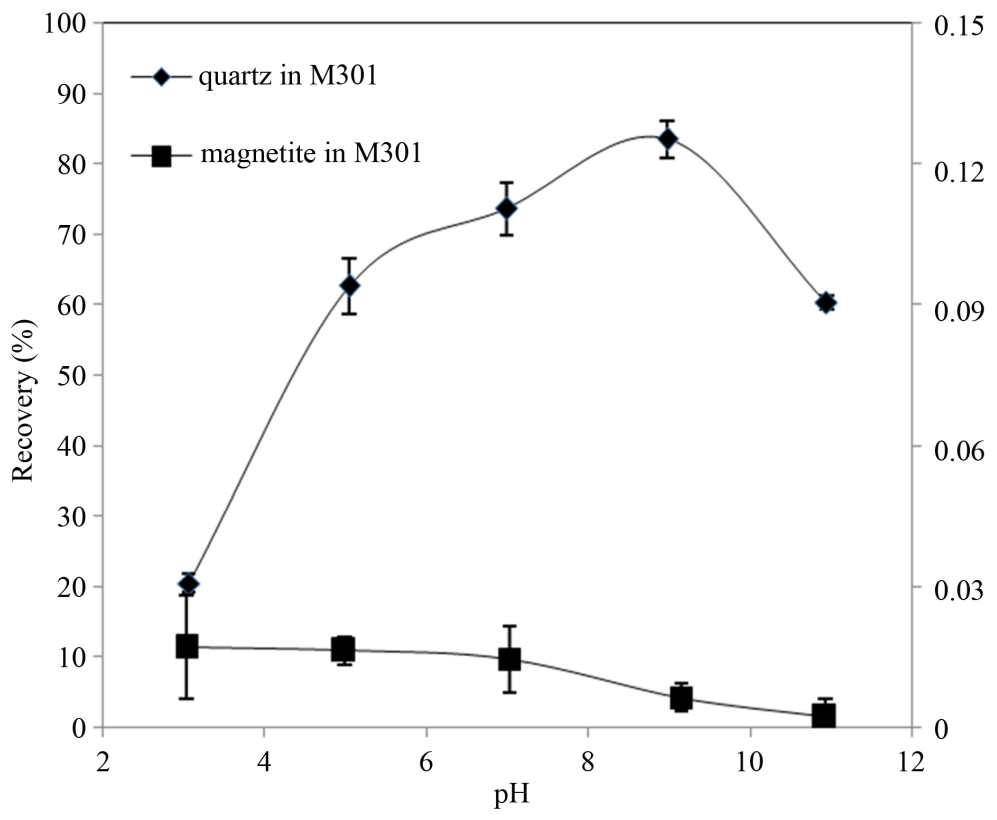

Figure 4. Floatability of quartz and magnetite as a function of pH with M301.

However, in high $\mathrm{pH}$ range $(\mathrm{pH}>7)$, the curves of quart and magnetite recoveries trend to merge, indicating that the selectivity of M302 becomes worse, although the recovery of quartz reaches the maximum of $91.27 \%$ at $\mathrm{pH}$ $=9$.

\subsection{Surface Potential Measurements}

Electrokinetic measurements are usually used to delineate interfacial phenomena where electrical double layer effects are of relevance to flotation. In this study, we use surface (zeta) potential to investigate the mechanism of interaction between cationic collectors and mineral particles. The zeta potentials of quartz and magnetite in distilled water with $1 \mathrm{mM} \mathrm{KCl}$, in the absence and in the presence of $1 \times 10^{-4} \mathrm{~mol} / \mathrm{L}$ collector solution were measured, and the results are given in Figure 6 and Figure 7, which show the value of potentials on the surface of 


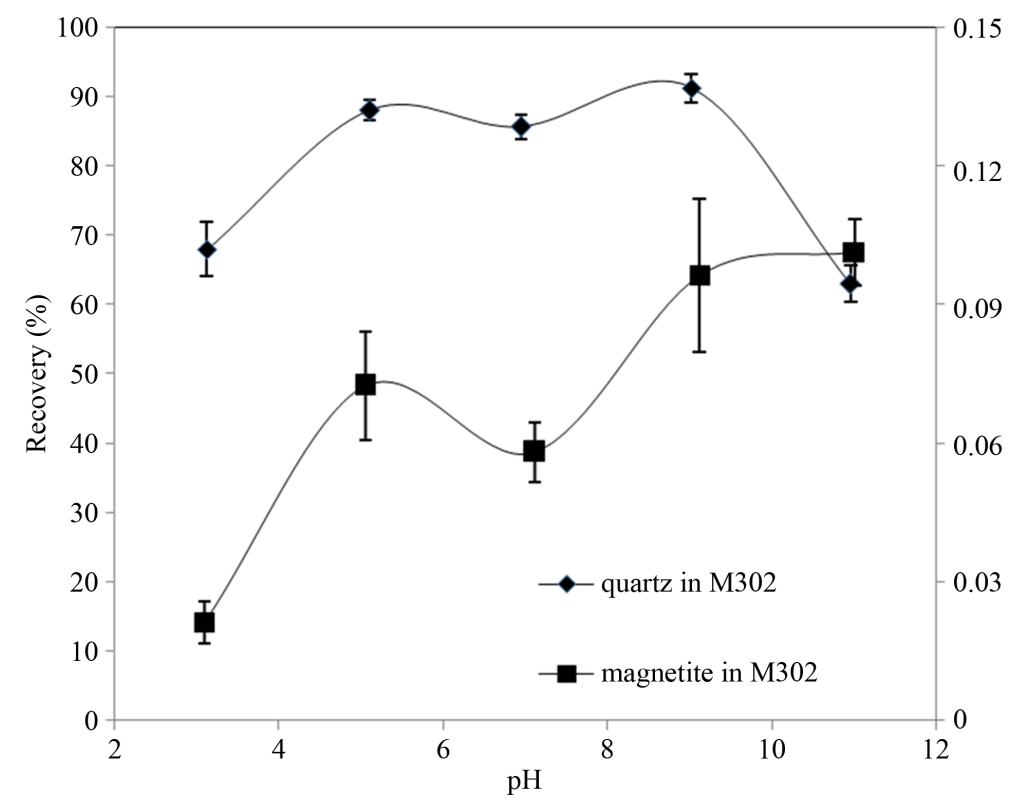

Figure 5. Floatability of quartz and magnetite as a function of pH with M302.

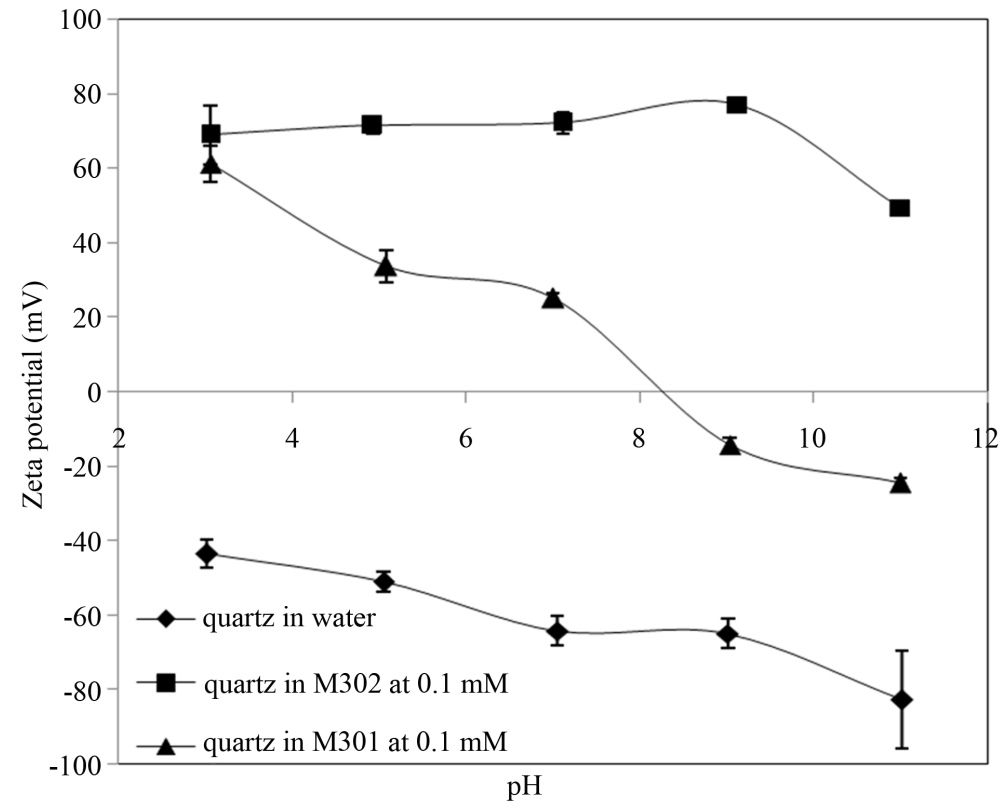

Figure 6. Effect of M301 and M302 on zeta potential of quartz.

quartz and magnetite reduces in magnitude in the presence of M301 and M302 in the pH range of 3 - 11.

Figure 6 shows that when quartz in distilled water with $1 \mathrm{mM} \mathrm{KCl}$, the zeta potential of quartz is more negative in the full range of pH 3 - 11. In the presence of M301 and M302, the M302 has a stronger influence on the quartz than M301 at all pH values, and the zeta potential of quartz shows a pronounced shift of the curves towards more positive zeta potentials, indicating that electrostatic force is a definitely main mechanism in this flotation system. It has been commonly recognized that the interactions between minerals and the cationic collectors are both affected by physical electrostatic effects and hydrogen bonds [14]. In Figure 7, the PZC (point of zero charge) of magnetite is around 5.6. Magnetite is negatively charged when the $\mathrm{pH}>5.6$ in distilled water with $1 \mathrm{mM} \mathrm{KCl}$. The positively charged M301 or M302 absorbs on the magnetite surface through electrostatic interactions. When $\mathrm{pH}$ is lower than PZC of magnetite, the minerals carry positive charges on their surfaces and 


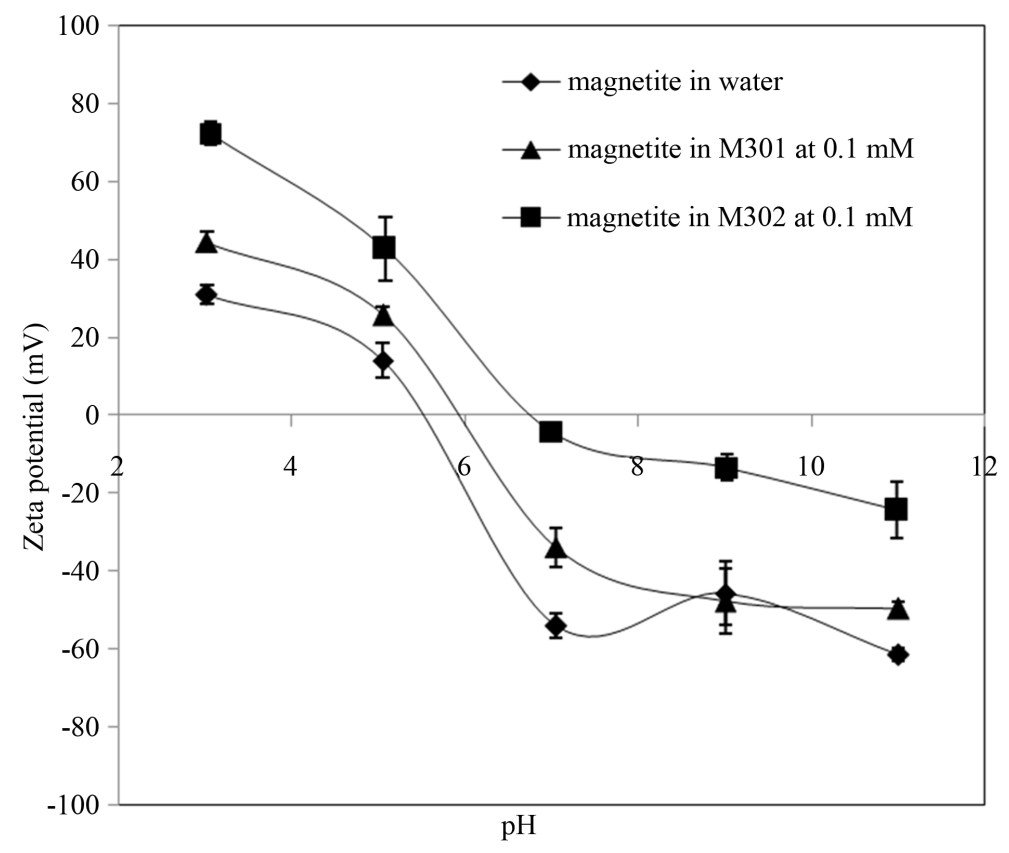

Figure 7. Effect of M301 and M302 on zeta potential of magnetite.

the cationic collectors are in a neutral, precipitated form. The collection ability of the cationic collector is attributed to the effect of H-bonds. With increasing $\mathrm{pH}$, hydrogen bond strength reduces and the floatability of magnetite is much affected. By comparing the results in Figure 4 and Figure 5, the zeta potentials of quartz change much more significantly than magnetite after adsorption of M302 and M301. It suggests that the changes of the zeta potential on quartz are much stronger than magnetite, which is in agreement with the microflotation results shown in Figure 4 and Figure 5.

\subsection{Biodegradability Evaluation}

The degradation curves of collectors are given in Figure 8. It can be seen that the curve of M301 is above that of M302 in the full range. In the period of 0 to 10 days, at the beginning the biodegradation rate of M301 increases quickly and then becomes stably, M302 increases slowly in the first 8 days, and then increases sharply. The two curves are close from 10th to 16th day. After that period, M301 and M302 biodegradation rate increases steadily, and the biodegradation rate of M301 is still higher than that of M302 for the following days. It indicates that quaternary ammonium compounds with one hydrocarbon chain biodegrade faster than the compounds with two due to the steric hindrance [15]. M301 and M302 are classified as readily degradable reagents according to the OECD 301B evaluation standard because the biodegradation rate of M301 and M302 at 28 days eventually reaches $97.26 \%$, and $80.32 \%$, respectively.

\section{Conclusion}

The flotation test results indicated that the separation of quartz from magnetite is feasible by using the new biodegradable quaternary ammonium collectors (M301 and M302). Both of them show strong collection ability in the microflotation tests at the optimum concentration of $1 \times 10^{-4} \mathrm{~mol} / \mathrm{L}$. The most favorable $\mathrm{pH}$ for separating quartz from magnetite in the presence of M301 or M302 under investigation is pH 8 - 9. M302 is more efficient than M301 in adsorbing onto the quartz surface. It is shown that quaternary ammonium compounds with one hydrocarbon chain biodegrade faster than compounds with two chains. The new quaternary ammonium collectors are readily biodegradable reagents.

\section{Acknowledgements}

This work is supported by National Natural Science Foundation of China (No. 51274158) and partially sup- 


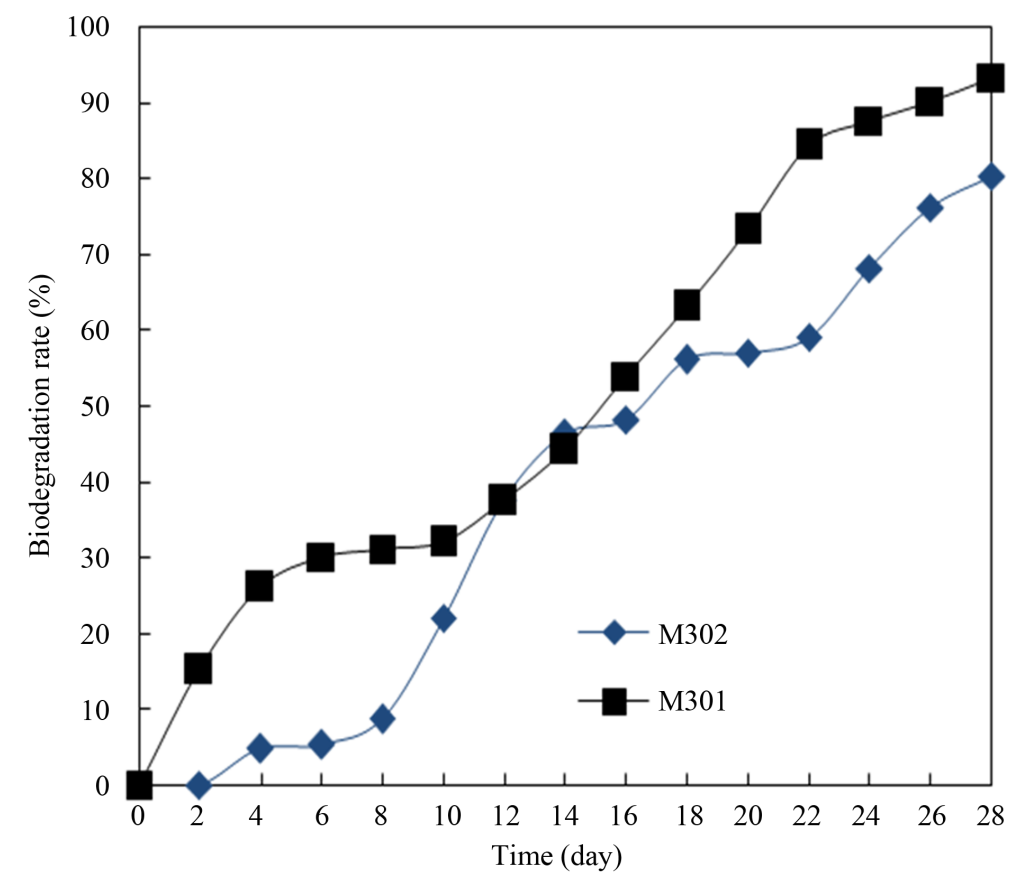

Figure 8. Biodegradation curves of M301 and M302.

ported by the China Scholarship Council (No. 201206950033) under the joint PhD student program.

\section{References}

[1] Fan, M., Luo, C., Wei, X. and Ni, B. (2013) Synthesis of Biodegradable Ester-Containing Quaternary Ammonium Salt by a Novel Route. Journal of the Taiwan Institure of Chemical Engineers, 44, 202-204. http://dx.doi.org/10.1016/j.jtice.2012.11.002

[2] Hu, Y.H., Yang, F. and Sun, W. (2011) The Flotation Separation of Scheelite from Calcite Using a Quaternary Ammonium Salt as Collector. Minerals Engineering, 24, 82-84. http://dx.doi.org/10.1016/j.mineng.2010.08.023

[3] Hu, Y., Chen, P. and Sun, W. (2012) Study on Quantitative Structure-Activity Relationship of Quaternary Ammonium Salt Collectors for Bauxite Reverse Flotation. Minerals Engineering, 26, 24-33. http://dx.doi.org/10.1016/j.mineng.2011.10.007

[4] Jiang, H., Xu, L.-H., Hu, Y.-H., Wang, D.-Z., Li, C.-K., Meng, W., et al. (2011) Flotation and Adsorption of Quaternary Ammonium Cationic Collectors on Diaspore and Kaolinite. Transactions of Nonferrous Metals Society of China, 21, 2528-2534. http://dx.doi.org/10.1016/S1003-6326(11)61046-7

[5] Deo, N. and Natarajan, K.A. (1998) Biodegradation of Some Organic Flotation Reagents Bybacillus Polymyxa. Bioremediation Journal, 2, 205-214. http://dx.doi.org/10.1080/10889869891214321

[6] Araujo, D.M., Yoshida, M.I., Takahashi, J.A., Carvalho, C.F. and Stapelfeldt, F. (2010) Biodegradation Studies on fatty Amines Used for Reverse Flotation of Iron Ore. International Biodeterioration \& Biodegradation, 64, 151-155. http://dx.doi.org/10.1016/j.ibiod.2010.01.004

[7] Van Ginkel, C.G. and Kolvenbach, M. (1991) Relations between the Structure of Quaternary Alkyl Ammonium Salts and Their Biodegradability. Chemosphere, 23, 281-289. http://dx.doi.org/10.1016/0045-6535(91)90184-F

[8] Li, Y.X., Mei, G.J. and Zhu, Y. (2011) Biodegradation of Modified Fatty Amine Flotation Collectors. 2011 5th International Conference on Bioinformatics and Biomedical Engineering, Wuhan, 10-12 May 2011, 1-4.

[9] Tehranibagha, A. and Holmberg, K. (2007) Cleavable Surfactants. Current Opinion in Colloid \& Interface Science, 12, 81-91. http://dx.doi.org/10.1016/j.cocis.2007.05.006

[10] Luczynski, J., Frackowiak, R., Wloch, A., Kleszczynska, H. and Witek, S. (2013) Gemini Ester Quat Surfactants and Their Biological Activity. Cellular and Molecular Biology Letters, 18, 89-101. http://dx.doi.org/10.2478/s11658-012-0041-4

[11] Tehrani-Bagha, A.R., Oskarsson, H., Van Ginkel, C.G. and Holmberg, K. (2007) Cationic Ester-Containing Gemini Surfactants: Chemical Hydrolysis and Biodegradation. Journal of Colloid and Interface Science, 312, 444-452. 
http://dx.doi.org/10.1016/j.jcis.2007.03.044

[12] Yamane, M., Toyo, T., Inoue, K., Sakai, T., Kaneko, Y. and Nishiyama, N. (2008) Aquatic Toxicity and Biodegradability of Advanced Cationic Surfactant APA-22 Compatible with the Aquatic Environment. Journal of Oleo Science, 57, 529-538. http://dx.doi.org/10.5650/jos.57.529

[13] Reuschenbach, P., Pagga, U. and Strotmann, U. (2003) A Critical Comparison of Respirometric Biodegradation Tests Based on OECD 301 and Related Test Methods. Water Research, 37, 1571-1582. http://dx.doi.org/10.1016/S0043-1354(02)00528-6

[14] Xia, L., Zhong, H., Liu, G., Huang, Z. and Chang, Q. (2009) Flotation Separation of the Aluminosilicates from Diaspore by a Gemini Cationic Collector. International Journal of Mineral Processing, 92, 74-83. http://dx.doi.org/10.1016/j.minpro.2009.02.012

[15] Qin, Y., Zhang, G., Kang, B. and Zhao, Y. (2005) Primary Aerobic Biodegradation of Cationic and Amphoteric Surfactants. Journal of Surfactants and Detergents, 8, 55-58. http://dx.doi.org/10.1007/s11743-005-0330-x 
Scientific Research Publishing (SCIRP) is one of the largest Open Access journal publishers. It is currently publishing more than 200 open access, online, peer-reviewed journals covering a wide range of academic disciplines. SCIRP serves the worldwide academic communities and contributes to the progress and application of science with its publication.

Other selected journals from SCIRP are listed as below. Submit your manuscript to us via either submit@scirp.org or Online Submission Portal.
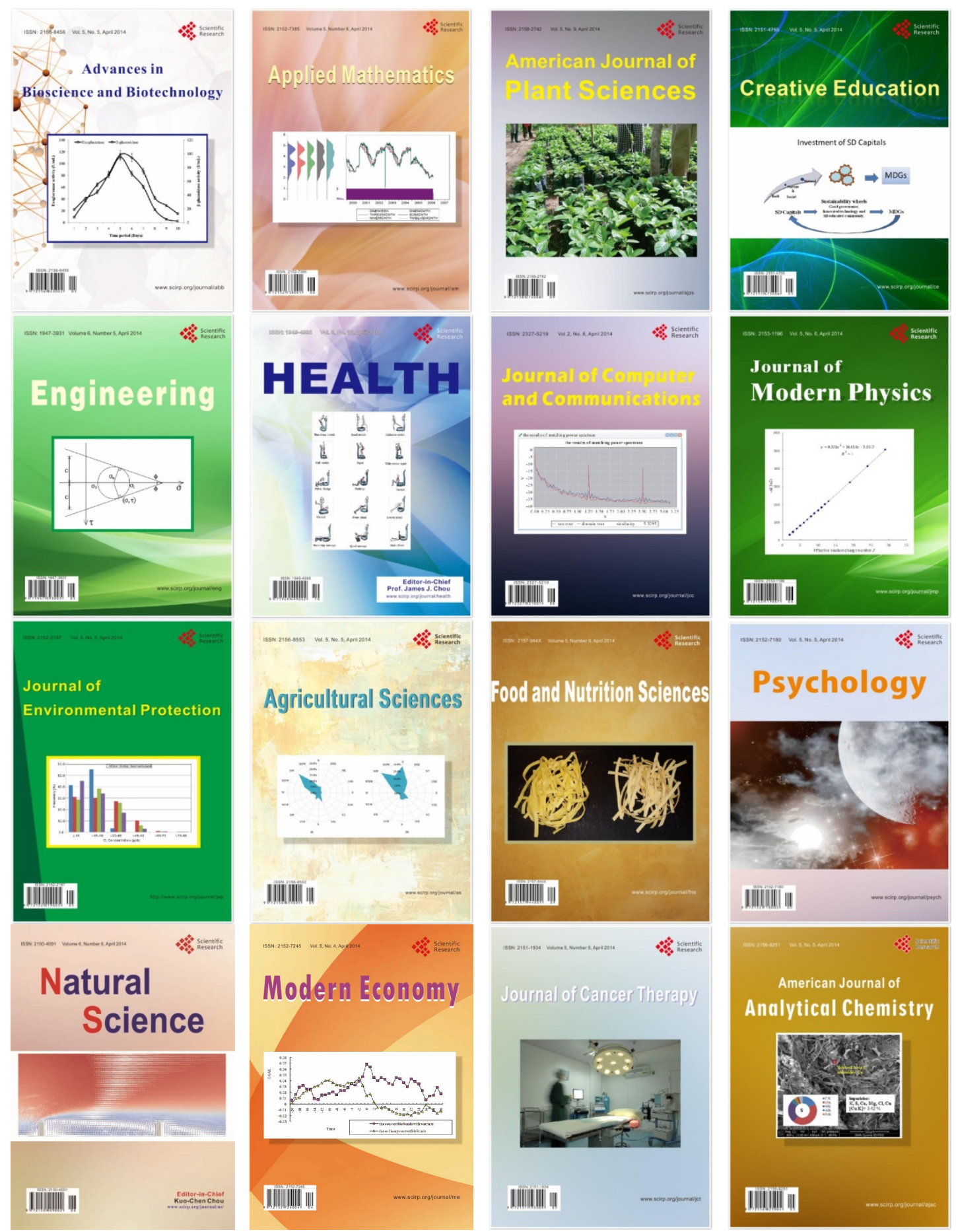